\title{
Antimicrobial properties of Vernonia amygdalina on Escherichia coli and Proteus species isolated from urine samples: Potential antimicrobial alternative for urinary tract infection
}

Edobor Peter Kenneth Imarenezor, Onolunosen Abel Abhadionmhen, Joyce Briska, Paula Paul Shinggu and Sunday Danya

Tropical Diseases Unit, Department of Microbiology, Faculty of Pure and Applied Sciences, Federal University Wukari, Taraba State, Nigeria.

International Journal of Biological and Pharmaceutical Sciences Archive, 2021, 02(01), 127-134

Publication history: Received on 12 July 2021; revised on 19 August 2021; accepted on 21 August 2021

Article DOI: https://doi.org/10.53771/ijbpsa.2021.2.1.0074

\begin{abstract}
Vernonia amygdalina is a member of the Asteraceae family and a shrub of $2-3 \mathrm{~m}$ tall with a petiole leaf of about $6 \mathrm{~mm}$ wide and naturally distributed in many parts of West Africa. It is reported to have several health benefits including antimicrobial efficacy. The study assessed the antimicrobial effects of aqueous and ethanolic extracts of Vernonia amygdalina on clinical isolates of Escherichia coli and Proteus spp. Of the 41 urine samples collected included in this research, 21 clinical samples (urine) were collected from Kwararafa Hospital Wukari while the remaining 20 samples were taken from students of Federal University Wukari. Standard microbiological techniques were employed in this investigation. Extracts of the leaves were made using Ethanol and aqueous procedures. The antimicrobial activity of the extracts was tested using pathogenic isolates of Proteus species and Escherichia coli. It was observed that Escherichia coli were susceptible to both extracts of the leaf in high concentrations. The aqueous extract of the leaf shows moderate growth on the Proteus species but the ethanolic extract of the leaf presented significant antimicrobial activity on Proteus spp. This study has revealed greatly that extracts of Vernonia amygdalina in high concentration possess strong antimicrobial activities against the tested clinical isolates Proteus species and Escherichia coli with ethanolic extract of the leaves exhibiting greater antimicrobial significance against the tested clinical isolates compared to aqueous extracts of the leaves.
\end{abstract}

Keywords: Antimicrobial; Escherichia coli; Proteus species; Urine; Vernonia amygdalina

\section{Introduction}

Antimicrobial resistance (AMR) being a consequence of the vast genetic plasticity of microbial pathogens triggering specific rebellious reactions resulting in mutational adaptations and acquisition of genetic material has continued to cause serious threats to global efforts of antibiotic use in public health [1]. This occurrence has stimulated the insistent attention of medical professionals who now seek a global solution to supplementing chemotherapeutic efforts with herbal remedies of antimicrobial efficacy [2]. It is estimated that antibiotic-resistant pathogens are responsible for over 2 million illnesses and about 23,000 deaths annually in the U.S [3]. On a global scale over 700,000 deaths results from AMR, and could rise to about 10 million yearly by 2050 if adequate action is not taken [4]. According to a [3], AMR is estimated to force up to 24 million people into extreme poverty by the year 2030. Drug resistivity typically stems from drug overuse particularly on common illnesses and frequent infections such as Urinary Tract infections (UTI) [5]. It is

\footnotetext{
${ }^{*}$ Corresponding author Imarenezor, Edobor Peter Kenneth

Tropical Diseases Unit, Department of Microbiology, Faculty of Pure and Applied Sciences, Federal University Wukari, Taraba State, Nigeria.

Copyright (C) 2021 Author(s) retain the copyright of this article. This article is published under the terms of the Creative Commons Attribution Liscense 4.0.
} 
estimated that $50 \%$ of women and $10 \%$ of men will experience UTI in their lifetimes which may prompt indiscriminate antibiotic use thereby enhancing genetic mutation of uropathogens to assume antibiotic resistance [5].

Aerobic gram-negative bacilli, including the family of Enterobacteriaceae and non-lactose fermenting bacteria such as Escherichia coli and Proteus species, are chiefly responsible for UTI [6]. According to [7], Escherichia coli is the most isolated bacteria from UTI in clinical settings. Interestingly, owing to its sophisticated virulence factor particularly it's swarming and pleomorphic attributes, Proteus species has great uropathogenic potentials, causing about $10 \%$ of all reported UTI cases globally [8]. Proteus species are the leading cause of more complicated UTIs compared to other uropathogens [9].

Escherichia coli is a Gram-negative rod shape, facultative anaerobic bacteria. Escherichia coli is a ubiquitous bacterial which is commonly found in the lower intestines of warm-blooded organisms [10]. Although Escherichia coli are largely regarded as commensals, some isolates however have the potential to also cause disease. Apart from being an etiological agent of urinary tract infections, pathogenic Escherichia coli is also a leading cause of diarrhea, often with high mortality rates, in developing countries [11]. Proteus species are Gram-negative, pleomorphic bacteria and consist of Proteus mirabilis, Proteus. vugaris, Proteus penneri Proteus hauseri and Proteus myxofaciens are the five known Proteus species and Proteus mirabilis is the most isolated among others members of the species from clinical specimens, responsible for about $44 \%$ catheter-associated UTI in the United States [12]. Proteus is a free-living saprophyte in soil, vegetation, water, and sewage, and is found in the intestine of many healthy individuals [13]. Proteus species causes opportunistic infection in humans only when the virulent form of the organism leaves the intestinal tract [14]. The Urease producing organisms are is presents with bacteremia, pneumonia, and focal lesions in debilitated patients particularly those receiving contaminated intravenous infusions [13; 14]. The complicity of Proteus species in wound infection, meningitis in the neonate, and rheumatoid arthritis have also been reported by $[13 ; 15]$.

Worldwide, over 20,800 medically efficacious plants including fruits, leaves, and roots have been approved by WHO to be used for medical purposes [15]. Over 100 of the 2500 discovered medicinal species of plants in India are currently been produced in a large scale and used as mainstream medicine making the country the largest producer of medicinal plants in the world earning a reputation of "the Botanical Garden of the World" [15]. Many plants have continued to show efficacy against microorganisms. The recent discovery of Artemisinin, which is derived from Artemisia has recorded significant success in the fight against malaria in Africa and other tropics [16]. In Africa, Vernonia amygdalina has been ascertained to provide various culinary and medicinal properties with bacteriostatic and bactericidal effects on some organisms [17].

Vernonia amygdalina otherwise known as bitter leaf owing to its bitter taste is consumed either as a vegetable for cooking African soups or its extracts drank as tonics for the treatment of various illnesses [17]. Vernonia amygdalina, a member of the Asteraceae family is a shrub that grows in tropical Africa with a typical height of $2-5 \mathrm{~m}$ (6.6-16.4ft). The leaves are elliptical and up to $20 \mathrm{~cm}$ (7.9inch) long with a rough back [18]. It is also known in Hausa as "Shiwaka", in Yoruba as "Ewuro", in Igbo as "Onugbu", and in Edo as "Oriwo" [19]. The plant grows throughout tropical Africa, it is drought-resistant and thrives in a humid environment [18]. The leaves are green with a characteristic scent and a bitter taste and contains significant quantities of lipid [20], and carbohydrates [21]. Vernonia amygdalina fresh leaf had a moisture content of $83 \bullet 0 \%$; dry matter of $17 \bullet 02 \%$; protein $1 \bullet 30 \%$ and ash content $0 \bullet 50 \%$ [22].The Bitter leaf plant as it is locally called is claimed to be exhibit anti-helminthic and anti-malaria properties [23], as well as anti-tumorigenic properties [24]. Vernonia amygdalina serves as a medicinal herb in wildlife [25]. Other documented medicinal uses include the treatment of amoebic dysentery, wound healing, venereal diseases, hepatitis, and diabetes [26]. It is used in some parts of Africa to prepare cough remedies [27]. Vernonia amygdalina is increasingly becoming a strong candidate for prostate cancer management owing to its coumarins, flavonoids, sesquiterpene lactones and edotides composites [28; 29; 30]. Leaf extracts of Vernonia amygdalina have been observed by [31] to be effective against breast cancer in a concentrated and time-dependent manner. Interestingly, $[25 ; 31]$ observed in their zoonotic study that chimpanzees ingest the leaves when suffering from parasitic infection. [32] linked the extensive use of Vernonia amygdalina for various medical purposes especially in rural settings as first aids instead of chemotherapy to the poor socioeconomic conditions in many African homes. Extract of the bitter leaf had been reported to exert antibiotic action against drugresistant microorganisms [27; 33]. Consequently, this disciplined inquiry set to investigate the antimicrobial effectiveness of Vernonia amygdalina on Escherichia coli and Proteus species. 


\section{Material and methods}

\subsection{Collection and identification of plant samples}

Vernonia amygdalina were collected from the School Farm of Federal University Wukari and was identified by Dr. (Mrs.) Chibiya Paul Shinggu of the Department of Crop Production and Protection, Federal University Wukari, and transported to the Microbiological laboratory, Federal University Wukari.

\subsection{Preparation of dried extract of Vernonia amygdalina}

Fresh leaves of Vernonia amygdalina were air-dried in shade for 7-14days. The leaf extract was then prepared by grinding dried leaves using an electric blender and was successively soaked in different volumes of the extraction solvents of water and ethanol ranging from $5 \mathrm{~g}-10 \mathrm{ml}, 10 \mathrm{~g}-20 \mathrm{ml}, 15 \mathrm{~g}-30 \mathrm{ml}, 20 \mathrm{~g}-40 \mathrm{ml}, 25 \mathrm{~g}-50 \mathrm{ml}$, for some hours. The extracts were stored in a well corked universal bottle.

\subsection{Preparation of fresh extract of Vernonia amygdalina}

The leaves were washed with distilled water and grounded using a pestle and mortar to extract the water content. The plant was successively soaked in different volumes of the extraction solvents of water and ethanol ranging from 5g$10 \mathrm{ml}, 10 \mathrm{~g}-20 \mathrm{ml}, 15 \mathrm{~g}-30 \mathrm{ml}, 20 \mathrm{~g}-40 \mathrm{ml}, 25 \mathrm{~g}-50 \mathrm{ml}$, for some hours. The extracts were stored in a well corked universal bottle.

\subsection{Urine Sample collection}

Mid-stream urine samples were collected from twenty-one (21) in-patients and out-patients at Kwararafa Hospital, Wukari. Twenty (20) from on-campus students of Federal University Wukari. The samples were collected aseptically with hand gloves and in sterile urine containers. The samples were immediately labeled and taken to the laboratory for investigation.

\subsection{Preparation of Media}

Cysteine lactose-electrolyte deficient agar (CLED), MacConkey agar, and Nutrient agar prepared with strict adherence to the manufacturer's instructions, were used for culturing in this study

\subsection{Culture of urine specimen}

$1 \mathrm{ml}$ of the urine sample was poured into Petri plates containing freshly prepared nutrient agar, Cysteine lactoseelectrolyte deficient agar (CLED), and MacConkey agar respectively, and rocked thereafter, were allowed to solidify. The plates were then incubated at $37^{\circ} \mathrm{C}$ for 24 hours for further examination.

\subsection{Isolation and identification of bacteria}

Distinct colonies of morphological characterization of Escherichia coli and Proteus specie on the cultured plates were carefully observed for. Noticeable colonies were then sub-cultured into Nutrient agar and were incubated for $37 \mathrm{oC}$ for 24hours. Biochemical reaction test were carried out on these colonies.

\subsection{Identification and characterization of bacterial isolates}

Bacterial identification was carried out by conventional biochemical methods according to the standard microbiological techniques. A recommended by [34] Catalase, Indole, Methyl Red, and Sugar fermentation tests were the biochemical tests carried out for the identification and characterization of Escherichia coli and Proteus specie which are the organisms under investigation for this research.

\subsection{Antimicrobial Test of bitter leaf extract on the isolates}

Escherichia coli and Proteus species were tested against the aqueous and ethanolic extracts of bitter leaf for antimicrobial efficacy on Nutrient agar using the agar dilution method.

$1 \mathrm{ml}$ of the prepared extracts was added to each Petri plate using the pour plate method. The nutrient agar was poured into the plates, rocked and mixed homogeneously with the extracts an allowed to solidify. The plates were allowed to stand for 30 minutes; the test organisms were streaked uniformly on nutrient agar media and were labeled appropriately. 
The cultures were incubated for $24-48$ hours at $37^{\circ} \mathrm{C}$ before final readings were taken. Control plates were also prepared for each test organism without the addition of extracts.

\section{Results}

As shown in Table 1, Streptococcus species, Staphylococcus aureus, Stahylococcus epidermidis, Escherichia coli, Pseudomonas species, Klebsiella species, and Proteus species were clinically isolated and identified from the urine sample collected. The table also represents their respective morphological and biochemical characteristics. The respective antimicrobial effectiveness of the fresh and dried extracts of Vernonia amygdalina in different concentrations on the test organisms, Escherichia coli, and Proteus is illustrated in Table 2 and 3. Figures 1 and 2 are histograms representing the results in Tables 2 and 3.

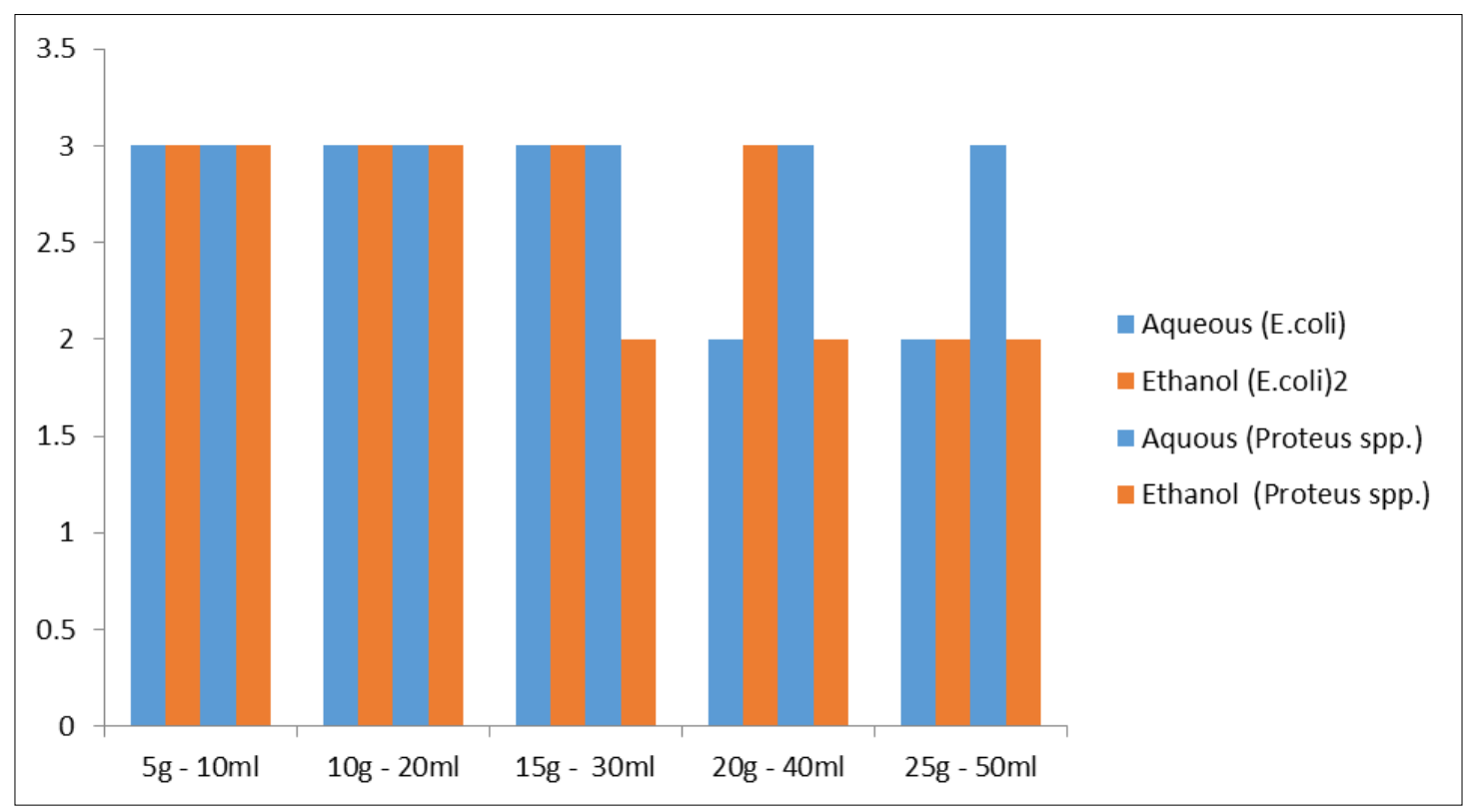

Figure 1 Effect of aqueous and ethanol extracts of fresh bitter leaf on Escherichia coli and Proteus spp

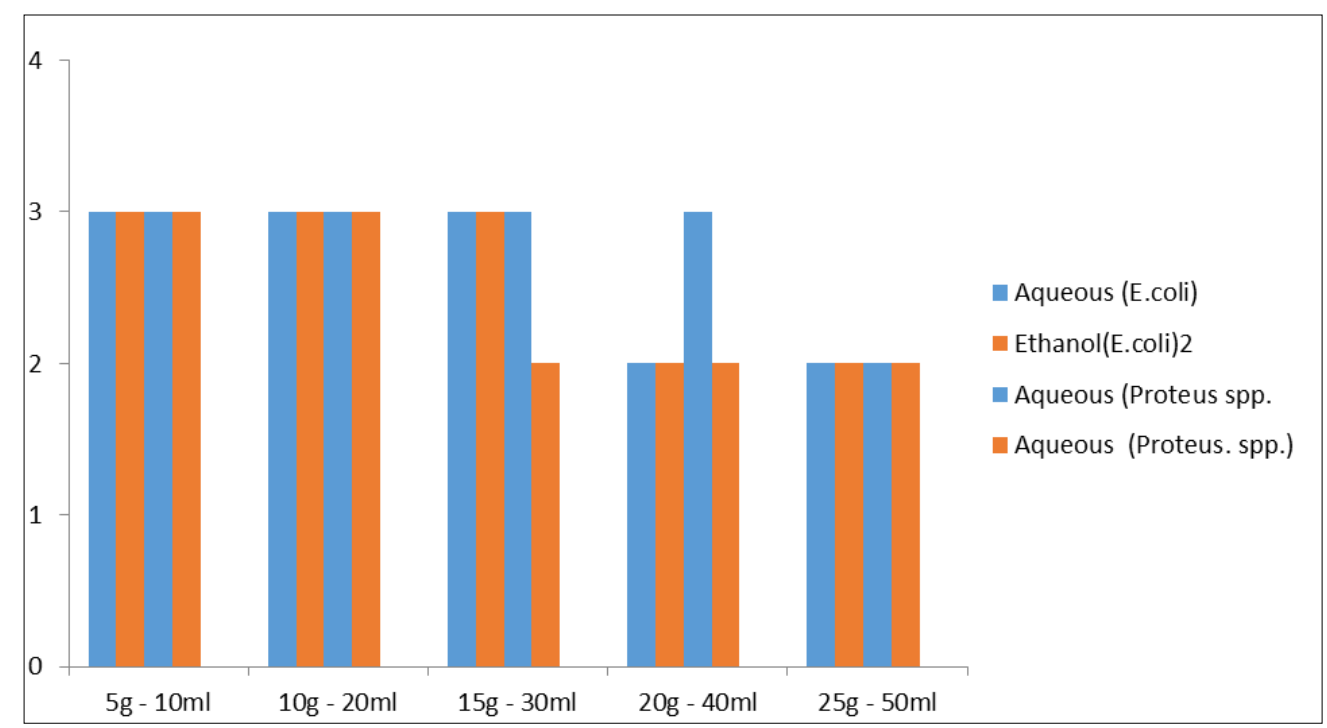

Figure 2 Effect of aqueous and ethanol extracts of dried bitter leaf on Escherichia coli and Proteus spp 
Table 1 Identification of bacteria isolated from clinical (urine) samples

\begin{tabular}{|c|c|c|c|c|c|c|c|c|c|c|c|c|}
\hline \multirow{2}{*}{ Isolates } & \multirow{2}{*}{$\begin{array}{l}\text { Morphological } \\
\text { characteristics }\end{array}$} & \multirow{2}{*}{$\begin{array}{l}\text { Gram } \\
\text { stainreaction }\end{array}$} & \multicolumn{9}{|c|}{ Biochemical Tests } & \multirow{2}{*}{ Bacterial Isolates } \\
\hline & & & Cat. & Coa & Ind & MR & Lac & Suc & Fru & Glu & Gal & \\
\hline $\mathrm{A}$ & $\begin{array}{l}\text { Medium, spherical, } \\
\text { yellow, dried and flat }\end{array}$ & +ve cocci (chains) & - & - & - & - & + & + & + & + & + & Streptococcus spp. \\
\hline $\mathrm{B}$ & $\begin{array}{l}\text { Medium, spherical, } \\
\text { yellow, dried and flat }\end{array}$ & +vecocci & + & + & - & + & + & + & + & + & + & Staphylococcus aureus \\
\hline $\mathrm{C}$ & $\begin{array}{l}\text { Large, spherical, white, } \\
\text { dried and raised }\end{array}$ & +veocci & + & + & - & - & - & + & + & + & + & Stahylococcusepidermidis \\
\hline $\mathrm{D}$ & $\begin{array}{l}\text { Small, spherical, pink, } \\
\text { mucoid and raised }\end{array}$ & -ve rods & + & - & + & + & + & + & + & + & + & Escherichia coli \\
\hline E & $\begin{array}{l}\text { Large, spherical, pink, } \\
\text { moist and raised }\end{array}$ & -ve rods & + & - & - & - & - & + & + & + & + & Pseudomonas spp. \\
\hline $\mathrm{F}$ & $\begin{array}{l}\text { Large, spherical, pink, } \\
\text { mucoid and raised }\end{array}$ & -ve rods & + & - & - & - & + & + & + & + & + & Klebsiella spp. \\
\hline G & $\begin{array}{l}\text { Large, spherical, pink, } \\
\text { moist and raised }\end{array}$ & -ve rods & + & - & + & - & + & + & + & + & + & Proteus spp \\
\hline
\end{tabular}

Key: $(-)$ = Negative, $(+)=$ Positive, Cat $=$ Catalase, Coa= Coagulase, Ind = Indole, MR = Methyl red, Lac $=$ Lactose, Suc $=$ Sucrose, Fru = Fructose,Glu=Glucose, Gal = galactose 
International Journal of Biological and Pharmaceutical Sciences Archive, 2021, 02(01), 127-134

Table 2 Effect of aqueous and ethanol extracts of fresh Bitter leaf on Escherichia coli and Proteus species

\begin{tabular}{|l|c|c|c|c|}
\hline \multirow{2}{*}{ Conc } & \multicolumn{2}{|c|}{ Escherichia coli } & \multicolumn{2}{c|}{ Proteus spp. } \\
\cline { 2 - 5 } & Aqueous & Ethanol & Aqueous & Ethanol \\
\hline $5 \mathrm{~g}-10 \mathrm{ml}$ & Moderate growth & Moderate growth & Moderate growth & Moderate growth \\
\hline $10 \mathrm{~g}-20 \mathrm{ml}$ & Moderate growth & Moderate growth & Moderate growth & Moderate growth \\
\hline $15 \mathrm{~g}-30 \mathrm{ml}$ & Moderate growth & Moderate growth & Moderate growth & Light growth \\
\hline $20 \mathrm{~g}-40 \mathrm{ml}$ & Moderate growth & Light growth & Moderate growth & Light growth \\
\hline $25 \mathrm{~g}-50 \mathrm{ml}$ & Light growth & Light growth & Moderate growth & Light growth \\
\hline
\end{tabular}

Table 3 Effect of aqueous and ethanol extracts of dried bitter leaf on Escherichia coli and Proteus species

\begin{tabular}{|l|l|l|l|l|}
\hline \multirow{2}{*}{ Conc. } & \multicolumn{1}{|c|}{ Escherichia coli } & \multicolumn{1}{c|}{ Proteus spp. } \\
\cline { 2 - 5 } & \multicolumn{1}{|c|}{ Aqueous } & \multicolumn{1}{c|}{ Ethanol } & \multicolumn{1}{c|}{ Aqueous } & \multicolumn{1}{c|}{ Ethanol } \\
\hline $5 \mathrm{~g}-10 \mathrm{ml}$ & Moderate growth & Moderate growth & Moderate growth & Moderate growth \\
\hline $10 \mathrm{~g}-20 \mathrm{ml}$ & Moderate growth & Moderate growth & Moderate growth & Moderate growth \\
\hline $15 \mathrm{~g}-30 \mathrm{ml}$ & Moderate growth & Moderate growth & Moderate growth & Light growth \\
\hline $\begin{array}{l}20 \mathrm{~g}-401 \mathrm{ml} \\
25 \mathrm{~g}-50 \mathrm{ml}\end{array}$ & $\begin{array}{l}\text { Light growth } \\
\text { Light growth }\end{array}$ & $\begin{array}{l}\text { Light growth } \\
\text { Light growth }\end{array}$ & $\begin{array}{l}\text { Moderate growth } \\
\text { Light growth }\end{array}$ & $\begin{array}{l}\text { Light growth } \\
\text { Light growth }\end{array}$ \\
\hline
\end{tabular}

\section{Discussion}

There exists a great variation in the antibacterial effect of aqueous and ethanol extracts of dried and fresh Vernonia amygdalina on Proteus species and Escherichia coli at different concentration levels of $5 \mathrm{~g}-10 \mathrm{ml}, 10 \mathrm{~g}-20 \mathrm{ml}, 15 \mathrm{~g}-30 \mathrm{ml}$ volume but significant at $20 \mathrm{~g}-40 \mathrm{ml}, 25 \mathrm{~g}-50 \mathrm{ml}$. On the one hand, aqueous and ethanolic extracts of fresh Vernonia amygdalina presented less antimicrobial effect on Proteus species and Escherichia coli in lower concentrations but, effective at higher concentration of both solutions as "light" growth of the organisms were observed except that, moderate growth of Proteus species was still seen even in high concentrations of aqueous extract of the fresh leave. It is evident from this study that the ethanolic extracts of both dried and fresh Vernonia amygdalina is more effective than the aqueous extracts on the test organisms under this study. This is consistent with the study conducted by [35] on the effects of ethanol and aqueous solutions as extraction solvents where the ethanolic extract was found to be more potent than the aqueous extract in extracting components of herbal plants with antimicrobial potentials. This is because, when compared to aqueous extraction, ethanol best extracts in higher concentrations antimicrobial phytochemicals of such as saponins and alkaloids, terpenes, steroids, coumarins, flavonoids, phenolic acids, lignans, xanthones, anthraquinones, edotides and sesquiterpenes [36]. On the other hand, a significant level of growth of Proteus species and Escherichia coli was observed in the aqueous and ethanolic extracts of dried Vernonia amygdalina at various concentration levels as "moderate" and "sparing" growth of both organisms were observed at low and high concentrations of aqueous and ethanolic solutions respectively. The distinction here is that the dried ethanolic and aqueous extracts of Vernonia amygdalina possess strong antimicrobial activities against the tested clinical isolate compared to the fresh extracts. This is consistent with the discoveries of [37] that naturally air-dried leaf extracts have reduced concentrations of toxic nonnutrients than fresh leaf extracts. The high concentration of nutrients and phytochemicals in plants is a consequence of a natural extraction process of its moisture content which supports microbial activity [38].

The present study has enormously presented that Vernonia amygdalina has antimicrobial potentials on Proteus species and Escherichia coli. This is in line with $[35 ; 38]$ which gave that ethanolic extracts of Tetrapleura tetrapteraon inhibit the growth of Streptococcus salivarus and Streptococcus mutans. In a comparative analysis of antimicrobial effects of extracts of Carica papaya leaves on bacterial and fungal isolates by [39], it was observed that C. papaya leaves showed better antibacterial activity than antifungal activity. Similar to the current study, [36; 39] had ascertained that the 
pharmacologic activities of Vernonia amygdalina extract are not limited to hypoglycaemic, antimalarial, hypolipide activities but extends to antibacterial as extracts of the plant inhibit the microbial growth of a panel of bacterial. Also, [40] had argued that extracts of Vernonia amygdalina has the potency of exerting antibiotic action against drug-resistant microorganisms. This is not unconnected to the fact that plants synthesize secondary metabolites that not only aid their reproduction but inform its defense mechanism against microbial attacks by disrupting microbial cell membrane functions and structure, also interfering with intermediary metabolism [41]. According to [42] plant products have the ability to interfere with "protein to protein" interactions, thereby triggering effective modulators of an immune response, mitosis, apoptosis, and signal transduction. The complex molecular features of plants are key in disrupting the development of antimicrobial resistance by bacterial [43]. Nonetheless, there have been arguments on microorganisms assuming resistance to antimicrobials of plant origin as in the case of synthetic drugs. [44] had maintained that there are not enough study to substantiate the claim of microorganism assuming resistance to plants of antimicrobial efficacy. Whereas, [45] still purports that there is possibility of bacteria developing resistance to herbal antimicrobial therapy. These discrepancies, necessitates the need for extensive research in this regard.

\section{Conclusion}

This research concludes by noting the great potentials which plants have continued to show in supplementing chemotherapeutic advancement in public health particularly in the era of antimicrobial resistance to existing drugs of choice. Ultimately, the extracts of Vernonia amygdalina has been observed to inhibit the growth of Proteus species and Escherichia coli and consequently recommended as a good natural antimicrobial candidate for advancing the therapeutic efforts of treating clinical cases of multi-drug resistant uropathogens.

\section{Compliance with ethical standards}

\section{Acknowledgments}

We thank the Director and staff of SOMOS Laboratory, Ekpoma, Edo State, Nigeria for the use of their Laboratory Equipment for various Analysis.

\section{Disclosure of conflict of interest}

No conflict of interest reported, Authors unanimously agree with the publication of this scientific work.

\section{References}

[1] Abosi AO, Raseroka BH. In vivo antimalarial activity of Vernonia amygdalina. British Journal of Biomedical Science. 2003; 60: 89-91.

[2] Adesanoye OA, Farombi E0. Hepatoprotective effect of Vernonia amygdalina astereaeain rats treated with carbontetracholide. Experimimental and Toxicologic Pathology. 2010; 62: 197-206.

[3] Akinpelu DA. Antimicrobial activity of Vernonia amygdalina leaves. Fitoterapia. 2000; 70: 432-434.

[4] Almabruk KH, Dinh LK, Philmus B. Self-resistance of natural product producers: Past, present and focusing on self-resistant protein variants. ACS Chem. Biol. 2018; 13: 1426-1437.

[5] Amira OC, NU Okubadejo. Frequency of complementary and Alternative Medicines utilization in hypensive urban tertiary care centre in Nigeria. BMC Complementary and Alternative Medicines. 2007.

[6] Aruoma OI, Sun B, Fuji H, Neergheen VS, Bahorun T, Kang KS, Sung MK. Low molecular proanthocyamidin dietary biofactor oligonol: Its modulation of oxidative stress, bioefficacy, neuroprotection, food application and chemoprevention potentials. Biofactors. 2006; 27: 245 - 265.

[7] Bebell Lisa. Antibiotic-resistant urinary tract infections are on the rise. 2019.

[8] Bhatia R, Ichhpujani RL.Essentials of Medical Microbiology, 4th edition. Published by Jaypee Brothers Medical Publishers (P) Ltd, B-3 EMCA House, 23/23B Ansari Road, India. 2008; 500.

[9] Borne Mehrad, Nina M, Clark George G. Zhanel, Joseph P Lynch. Antimicrobial Resistance in Hospital-Acquired Gram-Negative Bacterial Infections: American College of Chest Physicians. May 2015; 147(5): 1413-1421.

[10] Centers for Disease Control and Prevention. Antibiotic Resistance Threats in the United States. 2013. 
[11] Cheesebrough M. District Laboratory practice in Tropical Countries. 2008.

[12] Chelsie E Armbruster, Harry L, T Mobley. Merging mythology and morphology: The multifaceted lifestyle of Proteus mirabilis Nat Rev Micro. 2012; 10: 743-754.

[13] Dahanukar SA, Kulkarni RA, Rege NN. Pharmacology of Medicinal plants and natural products.International Journal of Pharmacology. 2000; 32: 81-118.

[14] Ejoh AR, Djuikwo VN, Gouado I, Mbofung CM. Nutrition Components of some non-conventional leafy vegetables consumed in Cameroon. Pakistan Journal of Nutrition. 2007; 6(6): 712-717.

[15] Eleyinmi AF, Sporns P, Bressler DC. Nutritional composition of Gongronema latifolium and Vernonia amygdalina. Nutrition of Food Science. 2008; 38: 99-109.

[16] Ephraim KD, HA Salami, TS Osewa. The effect of aqueous extract of Ocinum gratissium on haematological and biochemical parameters in rabbits. African Journal of Biomedical Resources. 2000; 3: 175-179.

[17] Jose M. Munita and Cesar A. Arias. Mechanisms of Antibiotic Resistance. Microbiol Spectr. April 2016; 4(2).

[18] Gberikon GM, Adeoti II, Aondoackaa AD. Effect of Ethanol and Aqueous Solutions as Extraction Solvents on Phytochemical Screening and Antibacterial Activity of Fruit and Stem Bark Extracts of Tetrapleura tetrapteraon Streptococcus salivarus and Streptococcus mutans: Int.J.Curr.Microbiol.App.Sci. 2015; 4(5): 404-410.

[19] Getenet Beyeneand and Wondewosen Tsegaye. Bacterial Uropathogens in Urinary Tract Infectionand Antibiotic Susceptibility Pattern in Jimma University Specialized Hospital, Southwest Ethiopia: Ethiop J Health Sci. Jul 2011; 21(2): 141-146.

[20] Hassan SW, Umar RA, Matazu IK, Maishanu AY, Abbas AY Sani AA. The Effect of Drying Method on the Nutrients and Non-Nutrients Composition of Leaves of Leptadenia hastata (Asclipiadaceae). Asian Journal of Biochemistry. 2007; 2: 188-192.

[21] Ijeh II, Ejike CE. Current Perspectives on the Medicinal Potentials of Vernonia Amygdalina Del. Journal of Medicinal plants Research. 2011; 5: 1051-1061.

[22] Imaga NO, Banigbetan DO. In vivo biochemical assessment of aqueous extract of Vernonia amygdalina bitter leaf. International Journal of Nutrition and metabolism. 2013; 52: 22-27.

[23] Izevbigie EB, Bryant JL, Walker A. A novel natural inhibitor of extracellular signal-regulated kinases and human breast cancer cell growth. Experimental Biology and Medicine. 2004; 229: 163-169.

[24] Jessica N Schaffer, Melanie M Pearson. Proteus mirabilis and Urinary Tract Infection: Micobiol spectr. Oct 2015; 3(5): 10.1128

[25] Jim O’Neill. Review on Antimicrobial Resistance: tackling drug-resistant infections from an economic and social perspective. 2016.

[26] Jisaka M, Ohigashi H, Takagaki T, Nozaki H, Tada T, Hirota M, Irie R, Huffman MA, Nishida T, Kaji M, Koshimizu K. Bitter steroid glucosides, Vernoniosides A1, A2 and A3 and realted B1 from a possible medicinal plant, Vernonia amygdalina, used by wild chimpanzees. Tetrahedron. 2002; 48: 625-632.

[27] Koshimizu K, Ohigashi H, Huffman MA. Use of Vernonia amygdalina by wild chimpanzee: Possible roles of its bitter and related constituents. Physiology and Behavior. 2000; 56: 1209-1216.

[28] Kupchan SM, Hemingway RJ, Karim A, Werner D. Tumor inhibitors. XLVII. Vernodalin and vernomygdin, two new cytotoxic sesquiterpene lactones from Vernonia amygdalina. Journal of Organic Chemical. 2000; 34: 3908-3911.

[29] Morris A, A Barnett, O Burrows. Effect of processing on nutrient content of foods. Cajarticles. 2004; 37: 160-164.

[30] Oboh FO, Masodje HI. Nutrional and antimicrobial properties of Ocimum gratissimum leaves.Journal of Biological Science. 2009; 9(4): 377-380.

[31] Ody P. The Complete Medicinal Herbal: A Practical Guide to the Healing Properties of Herbs. Skyhorse Publishing Inc.; New York, NY, USA. 2017.

[32] Okunola A Alabi, Muyideen T Haruna, Chinedu P Anokwuru, Tomisin Jegede, Harrison Abia, Victor U. Okegbe, Babatunde E Esan. Comparative studies on antimicrobial properties of extracts of fresh and dried leaves of Carica papaya on clinical bacterial and fungal isolates: Adv. Appl. Sci. Res. 2012; 3(5): 3107-3114.

[33] Quinn PJ, Markey BK, Leonard FC, Fitz Patrick ES, Fanning S, Hartigan PJ. Enterobacteriaceae. In Veterinary Microbiology and Microbial Diseases, 2nd ed.; Wiley and Blackwell: Hoboken, NJ, USA. 2011; 263-286. 
[34] Reker D, Rodrigues T, Perna AM, Schenider P. Revealing the macromolecular targets of complex natural products. Nat. Chem. 2014; 6: 1072-1078.

[35] Rozalski A, Torzewska A, Moryl M, Kwil I, Maszewska A, Ostrowska K, Drzewiecka D, Zablotni A, Palusiak A, Siwinska M, Staczek P. Proteus sp. - an opportunistic bacterial pathogen - classification, swarminggrowth, clinical significance and virulence factors.Folia Biologica et Oecologica. 2012; 8: 1-17.

[36] Ruddaraju LK, Pammi SVN, Guntuku GS, Padavala VW. Kolapalli V.R.M. A review on anti-bacterial to combat resistance: From ancient era of plants and metals to present and future Perspectives of green nano technological combinations. Asian J. Pharm. Sci. 2019.

[37] Sani Ali Audu Alemika Emmanuel Taiwo Abdulraheem Rafat Ojuolape Abdulkareem Sikirat Sani Abdulraheem Ramat, Bukola Ilyas Mohammed. A Study Review of Documented Phytochemistry of amygdalina (Family Asteraceae) as the Basis for Pharmacologic Activity of Plant Extract: Journal of Natural Sciences Research ISSN 2224-3186 (Paper) ISSN 2225-0921 (Online). 2012; 2(7).

[38] Shen Q, Zhang L, Liao Z, Brodelius PE. The Genome of Artemisia annua Provides Insight into the Evolution of Asteraceae Family and Artemisinin Biosynthesis. Mol. Plant. 2018; 1: 776-788.

[39] Uttpal Anand, Nadia Jacobo-Herrera, Ammar Altemimi, Naoufal Lakhssassi. A Comprehensive Review on Medicinal Plants as Antimicrobial Therapeutics: Potential Avenues of Biocompatible Drug Discovery: Metabolites. Nov 2019; 9(11): 258.

[40] Vadhana P, Singh BR, Bharadwaj M, Singh SV. Emergence of herbal antimicrobial drug resistance in clinical bacterial isolates. Pharm. Anal. Acta. 2015; 6: 434.

[41] Van den Beld MJ, Reubsaet FA. Differentiation between shigella, enteroinvasive Escherichia coli (EIEC) and noninvasive Escherichia coli. European Journal of Clinical Microbiology and Infectious Disease. 31: 899-904.

[42] Vlietinck AJ, Hoof LV, Totte J, Lasure A, Berghe DV. Screening of hundred Rwandese medicinal plants for antimicrobial and antiviral properties. Journal of Ethnopharmacology. 2000; 46: 31-47.

[43] Wall MG, Wani MC, Manikuma G, Abraham P, Taylor H, Hughes TJ, Warner J, Macgivney R. Plants antimutagenic agent, flavonoids. Journal of natural production. 2002; 51: 1084-1089.

[44] World Health Organisation (WHO). New Report Calls for Urgent action to avert antimicrobial resistance crisis. International Organizations unites to combat drug-resistant infections and prevent staggering number of deaths each year. April 2019/Joint News Release/ New York. 2019.

[45] Yuan F, Huang Z, Yang T, Wang G, Li P, Yang B, Li J. Pathogenesis of Proteus mirabilis in Catheter-Associated Urinary Tract Infections: Urol Int. 2021; 105: 354-361. 